\title{
Biologiczna rola prolakłyny
}

\section{Biological role of prolactin}

\author{
Anna M. Badowska-Kozakiewicz \\ Zakład Biofizyki i Fizjologii Człowieka Warszawskiego Uniwersytetu Medycznego; \\ kierownik Zakładu: prof. dr hab. n. med. Jacek Przybylski
}

Przegląd Menopauzalny 2012; 4: 305-308

\section{Streszczenie}

Prolaktyna (PRL) swoją strukturą przypomina hormon wzrostu oraz ludzki laktogen łożyskowy. Wydzielana jest przez komórki laktotropowe przysadki mózgowej, a jej synteza i sekrecja są regulowane przez podwzgórzowy hormon hamujący zwany dopaminą. Biologiczna rola PRL została dobrze poznana w laktopoezie i laktacji, ale jej istotną rolę stwierdzono również w prostacie i na różnych etapach rozwoju raka piersi. Najnowsze badania potwierdzają, że PRL nie jest wydzielana tylko przez przysadkę, ale także przez komórki prawidłowego gruczołu piersiowego i nowotworowego. Rola i obszar działania PRL w rozwoju raka piersi nie są dokładnie wyjaśnione. Dane z piśmiennictwa dotyczące ekspresji receptorów PRL w raku piersi u kobiet są bardzo skąpe. Wiadomo, że ma miejsce ekspresja receptorów PRL w prawidłowym gruczole sutkowym i raku piersi, lecz nie uzyskano odpowiedzi co do związku tej ekspresji z innymi czynnikami uważanymi za markery prognostyczne, jak aktywność proliferacyjna, stopień histologicznej złośliwości czy ekspresja receptorów estrogenowych.

Słowa kluczowe: prolaktyna (PRL), rak piersi, rak prostaty, hiperprolaktynemia, laktacja.

\section{Summary}

Prolactin (PRL) is a peptide hormone primarily associated with lactation. It is synthesized and secreted by lactotrope cells in the adenohypophysis. It is also produced in other tissues including the breast and the decidua. Pituitary prolactin secretion is regulated by neuroendocrine neurons in the hypothalamus, most importantly by neurosecretory dopamine neurons of the arcuate nucleus, which inhibit prolactin secretion. Prolactin has many effects: it plays a role in processes such as reproduction, fat metabolism, hair shedding and immune response, the most important of which is to stimulate the mammary glands to produce milk (lactation). Prolactin has been found to stimulate proliferation of oligodendrocyte precursor cells. The activation of the prolactin-prolactin receptor complex has been recognized as an important mechanism in the induction and progression of mammary tumors, but it is not a major cause of their genesis.

Key words: prolactin (PRL), lactation, hyperprolactinemia, prostate, breast cancer.

\section{Budowa prolaktyny}

Prolaktyna (PRL) jest polipeptydem kodowanym przez pojedynczy gen zlokalizowany na krótkim ramieniu 6. chromosomu [1]. Pod względem chemicznym jest białkiem składającym się ze 199 aminokwasów, o masie cząsteczkowej 23,4 kDa [2]. Swoją strukturą przypomina hormon wzrostu oraz ludzki laktogen łożyskowy [3]. W obrębie przysadki mózgowej i w surowicy wykryto jej niejednorodne odmiany o różnym ciężarze cząsteczkowym. Na tej podstawie wyróżniono kilka odmian biologicznie czynnej PRL:
- mała - tzw. forma monomeryczna o masie cząsteczkowej ok. $23 \mathrm{kDa}$, to bardzo aktywny biologicznie rodzaj PRL, wykazuje duże powinowactwo z receptorami; duża - tzw. forma dimeryczna o masie cząsteczkowej ok. 50 kDa, będąca mieszanką drugorzędowych i trzeciorzędowych struktur hormonów;

- bardzo duża - tzw. forma polimeryczna o masie cząsteczkowej ok. 60-100 kDa, która wykazuje mniejsze powinowactwo z receptorami [4];

- glikozydowa - o masie cząsteczkowej ok. 25 kDa, charakteryzująca się mniejszą immunoreaktywnością niż odmiana mała. 
Czynniki wpływajqce na sekrecie fizjologia wydzielania i funkcje prolaktyny

Do podstawowych czynników mających wpływ na wydzielanie PRL należą: czynniki hamujące (prolactin-inhibiting factor - PIF), którym jest prawdopodobnie dopamina, i czynniki pobudzające (prolactin-releasing factor - PRF), które ujawniają się w sytuacji, gdy zachodzi potrzeba szybkiego wyrzutu hormonu do krwiobiegu (np. karmienie piersią) [5]. Do czynników pobudzających biosyntezę $\mathrm{i}$ uwalnianie PRL in vitro i in vivo zalicza się podwzgórzowy hormon uwalniający tyreoliberynę (thyrotropin-releasing hormone - TRH), wazoaktywny peptyd jelitowy (vasoactive intestinal peptide - VIP) zidentyfikowany w przewodzie pokarmowym i w ośrodkowym układzie nerwowym (OUN) oraz angiotensynę II $[6,7]$. Dodatni wpływ na wydzielanie PRL wykazują: estrogeny, oksytocyna, czynniki wzrostu [czynnik wzrostu fibroblastów 2 (fibroblast growth factor 2 - FGF-2), nabłonkowy czynnik wzrostu (epidermal growth factor - EGF)], histydyna, gonadoliberyna (gonadotropin-releasing hormone - GnRH) i serotonina [8]. Prolaktyna wydzielana jest głównie przez komórki laktotropowe przysadki mózgowej. Synteza i sekrecja tego hormonu są regulowane przez podwzgórzowy hormon hamujący zwany dopaminą, uwalniany z podwzgórza do przysadki naczyń wrotnych. Działa ona na receptory dopaminergiczne D2, które są obecne na powierzchni komórek laktotropowych, hamując $w$ ten sposób powstawanie PRL. Proces wydzielania PRL wzrasta w trakcie snu, wysiłku fizycznego i psychicznego. Każdy proces fizjologiczny czy patologiczny, który prowadzi do zmniejszenia ilości dopaminy docierającej do receptorów D2 komórek laktotropowych, w konsekwencji powoduje zwiększenie wydzielania PRL. Znanych jest wiele funkcji tego hormonu, lecz najlepiej poznany jest wpływ na procesy związane z laktacją i mammogenezą.

\section{Rola prolakłyny w laktopoezie i laktacji}

W okresie ciąży estrogeny powodują wzrost i namnożenie komórek laktotropowych przysadki mózgowej, co zwiększa wydzielanie PRL, której największe stężenie odnotowuje się przed porodem, po porodzie stężenie to zmniejsza się do wartości poprzedzających ciążę. Duże stężenie estrogenów hamuje działanie PRL na gruczoł piersiowy, dlatego też laktacja rozpoczyna się po porodzie, gdy zmniejsza się stężenie estrogenów. Zwiększenie wydzielania PRL i wzmożona synteza białka wydzielanego z mlekiem matki spowodowane są drażnieniem receptorów $w$ brodawce sutkowej przez ssącego noworodka. Prolaktyna w trakcie laktacji hamuje wydzielanie hormonów gonadotropowych, a to powoduje zatrzymanie owulacji i brak cykli miesiączkowych [9]. W doświadczeniach na zwierzętach wykazano, że PRL wpływa na całkowity rozwój gruczołu mleko- wego i jest niezbędna w sekrecji mleka. Przypisuje się jej również wyzwalanie instynktu macierzyńskiego [10].

\section{Hiperprolaktynemia}

Rozwój żeńskich narządów płciowych oraz ich prawidłowa funkcja i cykl płciowy są uwarunkowane aktywnością osi podwzgórze-przysadka-jajnik. Endokrynologiczne zaburzenia działania osi podwzgórze-przysadka nazywa się hiperprolaktynemią. Jest to zaburzenie polegające na stałym lub okresowym wzmożonym wydzielaniu PRL. Rozpoznanie hiperprolaktynemii ustala się na podstawie dwukrotnego oznaczenia stężenia PRL w surowicy: u kobiet jest to wartość > $20 \mathrm{ng} / \mathrm{ml}(>400 \mathrm{mU} / \mathrm{l})$, a dla mężczyzn > 15 ng/ml (> $300 \mathrm{mU} / \mathrm{l}$ ). Hiperprolaktynemia występuje częściej u kobiet niż u mężczyzn i pojawia się z częstością od 0,4\% w populacji zdrowych osób aż do 9-17\% u kobiet z zaburzeniami płodności. Hiperprolaktynemia powoduje zmniejszenie częstości wydzielania GnRH, zmniejszenie przedowulacyjnego wyrzutu luteiny (luteinizing hormone - LH) oraz zmniejszenie stężenia estradiolu (E2). W przebiegu tego zaburzenia znoszone jest także dodatnie sprzężenie zwrotne między estrogenami a gonadotropinami [3]. Hiperprolaktynemia może być powodowana przez czynniki fizjologiczne, farmakologiczne i patologiczne. Fizjologicznie dziesięciokrotne zwiększenie stężenia PRL obserwuje się w ciąży i u noworodków, zwiększone stężenie tego hormonu towarzyszy również wysiłkowi fizycznemu, aktywności seksualnej (drażnienie brodawek sutkowych i szyjki macicy), spożywaniu posiłków, zwłaszcza bogatych w tłuszcze i białka, hipoglikemii indukowanej insuliną. Wyróżnia się hiperprolaktynemię czynnościową i samoistną. Hiperprolaktynemia czynnościowa może być powodowana niedoczynnością tarczycy, niewydolnością nerek, niewydolnością wątroby, guzami przysadki mózgowej, a także może mieć charakter polekowy. Wśród leków, które powodują hiperprolaktynemię, wymienia się: leki przeciwdepresyjne, przeciwwymiotne, poprawiające perystaltykę, obniżające ciśnienie krwi. Zjawisko hiperprolaktynemii dotyczy kobiet, a typowymi objawami klinicznymi tego zaburzenia są: hipogonadyzm z wtórnym brakiem miesiączki, nieregularne miesiączkowanie, zaburzenia fazy lutealnej, cykle bezowulacyjne z następującą niepłodnością. Do innych zaburzeń zalicza się: mlekotok, mastopatię włóknisto-torbielowatą, mastalgię, zespół napięcia miesiączkowego, umiarkowany hirsutyzm, zwiększenie masy ciała [11]. U kobiet zwiększone stężenie PRL objawia się przede wszystkim zaburzeniami ze strony cyklu miesiączkowego, rzadko w postaci zaburzeń seksualnych. Tymczasem u mężczyzn do najczęstszych zaburzeń wynikających ze zwiększonego stężenia tego hormonu należą zaburzenia seksualne: obniżone libido, zaburzenia erekcji [12]. U mężczyzn do niewielkiego zwiększenia stężenia tego hormonu dochodzi pod wpływem stresu lub też po po- 
siłku. Długotrwałe przyjmowanie kokainy, jak również palenie tytoniu o dużej zawartości nikotyny powodują niewielkie zwiększenie stężenia PRL [13].

\section{Znaczenie prolaktyny w prostacie}

W prowadzonych dotychczas badaniach wykazano istotną rolę PRL w prostacie. Stwierdzono, że hormon ten działa promitogennie na komórki nabłonka, co dowiodły badania na zwierzętach oraz izolowanych liniach komórkowych ludzkich i zwierzęcych [14]. Wpływa ona także na różnicowanie i sekrecję nabłonka gruczołowego [15], stymuluje syntezę matrycowego kwasu rybonukleinowego (messenger ribonucleic acid - mRNA) i kwasu deoksyrybonukleinowego (deoxyribonucleic acid - DNA) [16]. Większe stężenie PRL u starszych mężczyzn może wskazywać na współdziałanie w skorelowanych z wiekiem chorobach tego narządu - zapaleniach, łagodnym przeroście, dysplazji i nowotworach [17]. Podobnie badania doświadczalne przeprowadzone na zwierzętach wykazały udział PRL w patomechanizmie indukowanego zapalenia, dysplazji, a także transformacji nowotworowej [18]. Badania, które przeprowadzono na bioptatach ludzkiej prostaty, potwierdziły obecność receptorów PRL [19], która oddziałując poprzez swoje receptory, odgrywa ważną rolę w różnicowaniu, organogenezie, utrzymaniu prawidłowej trofiki prostaty, jak również uczestniczy w procesach chorobowych. W dysplazji ekspresja PRL się zwiększa, co sugeruje, że może ona odgrywać istotną rolę we wczesnej transformacji nowotworowej [20]. Doświadczenia przeprowadzone na zwierzętach wykazały proliferacyjny i stymulujący różnicowanie wpływ PRL poprzez aktywowanie szeregu kaskad białkowych i genów [21].

\section{Rola prolaktyny w rozwoju raka piersi}

Bardzo ciekawym spostrzeżeniem z punktu widzenia diagnostyki onkologicznej jest rola PRL na różnych etapach rozwoju raka piersi. Ponieważ gruczoł piersiowy podlega wpływom różnych hormonów: PRL, estrogenów, progesteronu, kortykosteroidów oraz hormonu wzrostu, to jego stan i funkcja warunkowane są homeostazą hormonalną w organizmie. Wiadome jest, że czynniki hormonalne odpowiadają za status fizjologiczny gruczołu sutkowego, ale w jaki sposób wpływają na proces kancerogenezy i przy użyciu jakich mechanizmów uruchamiają proces transformacji nowotworowej, nie jest do końca wyjaśnione, dlatego też w ostatnich latach nastąpił wyraźny postęp w badaniach dotyczących wpływu hormonów na rozwój raka piersi u kobiet. Ważną rolę $w$ transformacji nowotworowej gruczołu piersiowego odgrywają estrogeny - to im najwięcej uwagi poświęcają naukowcy. Badaczem, który zasugerował, że rak piersi jest nowotworem hormonozależnym, był Schinzinger. Miało to miejsce w 1889 r. [22]. Hipotezę Schinzingera potwierdził 7 lat później Beatson, wykonując obustronne usunięcie jajników u kobiety przed menopauzą z nieoperacyjną wznową raka piersi. Po upływie 8 miesięcy od zabiegu autor stwierdzit u chorej całkowity zanik tkanki nowotworowej [23]. Zaobserwowany związek między czynnością jajników a przebiegiem raka piersi stanowił punkt wyjścia do dalszych badań, które nabrały tempa po wyizolowaniu estrogenów z płynu pęcherzykowego jajników przez Allena w 1923 r. [24]. Przełom w badaniach nad hormonozależnością nastąpił w latach 60. XX w., kiedy to opisano mechanizm łączenia E2 i progesteronu ze swoistymi receptorowymi białkami cytoplazmatycznymi w komórkach. Dalsze badania nad receptorem estrogenowym potwierdziły, że oprócz udziału w fizjologicznych przemianach zachodzących w czasie rozwoju i różnicowania gruczołu piersiowego, odgrywa on również kluczową rolę w mechanizmie zależności hormonalnej raka piersi [25]. Odkrycie receptorów estrogenowych rzuciło nowe światło na biologię raka piersi. Rola i obszar działania PRL w rozwoju raka piersi u kobiet do dziś nie są wyjaśnione. W badaniach na zwierzętach stwierdzono jednoznacznie, że PRL ma właściwości kokancerogenne. Jednym z dowodów na to, że bierze ona udział w promocji kancerogenezy, jest reakcja na stosowanie związków zmniejszających stężenie tego hormonu, wyrażająca się spowolnieniem wzrostu i zmniejszoną częstością występowania nawrotów. Prolaktyna działa proliferacyjnie na komórki ją wydzielające (działanie autokrynne) oraz na komórki sąsiednie (działanie parakrynne). Z dotychczasowych badań wynika, że w materiale biopsyjnym raka piersi stwierdzono wysoką ekspresję PRL i jej receptorów, niezależnie od stężenia estrogenów i progesteronu, jednak nie wykazano związku tej ekspresji z innymi markerami prognostycznymi. Nadal skąpe są dane dotyczące ekspresji PRL i jej receptorów w raku piersi, ale duży krok w tym kierunku poczynił Touraine (1998), który stwierdził wysoką ekspresję genu receptora PRL w komórkach raka piersi w porównaniu z komórkami prawidłowymi [26]. Podobne rezultaty zostały uzyskane przez Peirce i Gill [27, 28], którzy wykazali u ponad 2/3 pacjentek z rakiem piersi wyższą ekspresję receptora PRL, co może sugerować, że hormon ma duże znaczenie diagnostyczne i uczestniczy w procesie kancerogenezy gruczołu piersiowego. Nad rolą PRL w rozwoju raka piersi zastanawiali się Clevenger i Goffin [29, 30], którzy stwierdzili, że działanie proliferacyjne autokrynne czy też parakrynne PRL w prawidłowych i nowotworowych komórkach gruczołu piersiowego może mieć miejsce, gdy spełnione są trzy warunki: PRL jest syntetyzowana i wydzielana w sutku, na powierzchni komórek epitelialnych obecny jest receptor PRL i w wyniku interakcji PRL z jej receptorem aktywacji ulega szlak przekazywania sygnału. Takie kryteria są uwzględniane w laboratoriach diagnostycznych, ale w przyszłości wiedza ta 
może być przydatna do stworzenia terapii mającej na celu przerwanie rozrostu w gruczole piersiowym wywotanego przez ten hormon [31]. Z dotychczasowych badań wynika, że aktywacja kompleksu PRL-PRL-R uznawana jest za istotny mechanizm w inicjacji i progresji nowotworów piersi, ale nie stanowi głównej przyczyny ich powstawania. Udział PRL w powstawaniu raka piersi nie jest do końca poznany. Powstają liczne pytania: Czy hormon może być traktowany jako promotor zmian nowotworowych w gruczole piersiowym? Czy PRL może powodować zaburzenia genetyczne? Czy istnieje różnica między działaniem PRL wydzielanej endokrynnie i tej, która jest syntetyzowana w gruczole piersiowym? Czy PRL zostanie uznana za przydatny marker w diagnostyce patomorfologicznej raka sutka u kobiet?

Obecny stan wiedzy sugeruje konieczność kontynuowania badań, a głównym ich celem powinno być wykazanie związku PRL z innymi markerami prognostycznymi mającymi duże znaczenie $w$ diagnostyce raka sutka u kobiet.

\section{Piśmiennictwo}

1. Owerbach D, Rotter WJ, Cooke NE, et al. The prolactin gen eis located on chromosome 6 in humans. Science 1981; 212: 815-6.

2. Pawelczyk L, Skrzypczak J, Pisarski T. Zespoły endokrynologiczne związane z zaburzeniami morfologii i funkcji jajników. W: Fizjopatologia jajnika. Podręcznik dla lekarzy i studentów. Pisarski T (red.). Termedia, Poznań 1998; 99.

3. Prabhakar VK, Davies JR. Hyperprolactinaemia. Best Pract Res Clin Obstet Ginecol 2008; 22: 341-53.

4. Serri O, Chik CL, Ur E, et al. Diagnosis and management of hyperprolactinemia. CMAJ 2003; 2: 23-32.

5. Jarząbek-Bielecka G, Radomski D, Nowaczyk A, et al. Analiza stężenia prolaktyny u dziewcząt bez cech endokrynopatii z zaburzeniami miesiączkowania i stresem w wywiadzie. Gin Prakt 2010; 1: 46-53.

6. Thompson D, Nett T. Thyroid stimulating hormone and prolactin secretion after thyrotropin releasing hormone administration to mares: dose response during estrus in summer. Domest Anim Endocrinol 1984; 1: 263-8.

7. Kaur K, Mandeep S, Virk S. Prolactinomas in infertility. Rev Gyn Prac 2003; 3: 180-7.

8. Genazzani A. Annals New York Academy of Sciences. Endocrynology. 2000.

9. Forsyth IA, Rossdale PD, Thomas CR. Studies on milk composition and lactogenic hormones in the mare. J Reprod Fertil Suppl 1975; 23: 631-635.

10. Tkaczuk-Włach J, Sobstyl M, Chołubek-Robak D, Jakiel G. Hiperprolaktynemia. Przegl Menopauz 2009; 2: 112-5.

11. Balercia G, Boscaro M, Lombardo F, et al. Sexual symptomem in endocrine diseases: psychosomatic perspectives. Psychoter Psychosom 2007: 76: $134-40$.
12. Mendelson JH, Sholar MB, Mutschler NH, et al. Effects of intravenous cocaine and cigarette smoking on luteinizing hormone, testosterone and prolactin in men. J Pharmacol Exp Ther 2003; 307: 339-48.

13. Clevanger CV, Furth PA, Hankinson SE, et al. The role of prolactin in mammary carcinoma. Endocr Rev 2003; 24: 1-27.

14. Freemark M, Driscoll P, Maaskant R, et al. Ontogenesis of prolactin receptors in the human fetus in early gestation. J Clin Invest 1997; 99: 1107-17.

15. Dillner K, Kindblom J, Flores-Moralers A, et al. Gene expression analysis of prostate hyperplasia in mice overexpressing the prolactin gene specifically in the prostate. Endocrinology 2003; 144: 4955-66.

16. Reiter E, Hennuy B, Bruynix M, et al. Effects of pituitary hormones on the prostate. The Prostate 1999; 38: 159-65.

17. Bartke A. Prolactin in the male: 25 years later. J Androl 2004; 25: 661-6.

18. Leav I, Merk FB, Lee KF, et al. Prolactin receptor in the developing human prostate and in hyperplastic, dysplastic and neoplastic leasions. Am J Pathol 1999; 154: 863-70.

19. Bostwick DG, Qian J. High grade prostatic intraepithelial neoplasia. Mod Pathol 2004; 17: 360-79.

20. Bole-Feysot C, Goffin V, Edery M, et al. Prolactin (PRL) and its receptor: actions, signal transduction pathways and phenotypes observed in receptor knockout mice. Endocr Rev 1998; 19: 225-68.

21. Schinizinger A. Uber carcinoma mammae. Bericht uber die Verhan dlundgen der Deutschen Gesellschaft fur Chirurgie, Kongressals Beilage zum Centralblatt fur Chir 1889; 29: 55. Za: Bland KI, Copeland EM. The Breast. WB Sanders Company, Philadelphia, 1991.

22. Beatson GT. On the treatment of inoperable cases of carcinoma of the mamma: suggestions for a new method of treatment with illustrative cases. Lancet 1896; 2: 104-7.

23. Allen E, Doisy EA. An ovarian hormone. Preliminary report on its localization, extraction and partial purification, and action in test animals. JAMA 1923; 81: 891-921.

24. Jensen EV. Proc Intl Congr Biochem, Vienna 1958. London, Pergamon Press 1960.

25. Ginsburg E, Vonderhaar BK. Prolactin synthesis and secretion by human breast cancer cells. Cancer Res 1995; 55: 2591-5.

26. Touraine P, Martini JF, Zafrani B, et al. Increased expression of prolactin receptor chain assessed by quantitative polymerase chain reaction in human breast tumors versus normal breast tissue. J Clin Endocrinol Metab 1998; 83: 667-74.

27. Peirce SK, Chen WY, Chen WY. Quantification of prolactin receptor mRNA in multiple human tissue and cancer cell lines by real time RT-PCR. J Endocrinol 2001; 171: 1-4.

28. Gill S, Peston D, Vonderhaar BK, Shousha S. Expression of prolactin receptors in normal, benign and malignant breast tissue: an immunohistological study. J Clin Pathol 2001; 54: 956-60.

29. Clevenger CV, Chang WP, Ngo W, et al. Expression of prolactin and prolactin receptor in human breast carcinoma. Evidence for an autocrine/ paracrine loop. Am J Pathol 1995; 146: 695-705.

30. Goffin V, Binart N, Clement-Lacroix P, et al. From the molecular biology of prolactin and its receptor to the lessons learned from knockout mice models. Genet Anal 1999; 19: 189-201.

31. Clevenger CV, Plank TL. Prolactin as an autocrine/paracrine factor in breast tissue. J Mammary Gland Biol. Neoplasia 1997; 2: 59-68. 